\title{
DK-RIM: Assisting Integrated Management of Lolium multiflorum, Italian Ryegrass
}

\author{
Mette Sønderskov ${ }^{1, *}$, Gayle J. Somerville ${ }^{1}$, Myrtille Lacoste ${ }^{2}{ }^{\mathbb{D}}$, Jens Erik Jensen ${ }^{3}$ and \\ Niels Holst ${ }^{1}$ (D) \\ 1 Department of Agroecology, Aarhus University, Forsøgsvej 1, 4200 Slagelse, Denmark; \\ gayesomerville@hotmail.com (G.J.S.); niels.holst@agro.au.dk (N.H.) \\ 2 Australian Herbicide Resistance Initiative, School of Agriculture and Environment, \\ University of Western Australia, Perth, WA 6009, Australia; myrtille.lacoste.ag@gmail.com \\ 3 Landbrug og Fødevarer F.m.b.a SEGES, Agro Food Park 15, DK-8200 Aarhus N, Denmark; jnj@seges.dk \\ * Correspondence: mette.sonderskov@agro.au.dk
}

Received: 21 May 2020; Accepted: 10 June 2020; Published: 16 June 2020

\begin{abstract}
Lolium multiflorum (annual Italian ryegrass) and other grass weeds are an increasing problem in cereal cropping systems in Denmark. Grass weeds are highly competitive and an increasing number of species develop resistance against the most commonly used herbicide modes of action. A diverse management strategy provides a better overall control of grass weeds and decreases the reliance on herbicides. The bio-economic decision support system, DK-RIM (Denmark-Ryegrass Integrated Management), was developed to assist integrated management of L. multiflorum in Danish cropping systems, based on the Australian RIM model. DK-RIM provides long-term estimations (10-year period) and visual outputs of L. multiflorum population development, depending on management strategies. The dynamics of L. multiflorum plants within the season and of the soil seed bank across seasons are simulated. The user can combine cultural weed control practices with chemical control options. Cultural practices include crop rotation changes, seeding density, sowing time, soil tillage system, and cover crops. Scenarios with increasing crop rotation diversity or different tillage strategies were evaluated. DK-RIM aims at being an actual support system, aiding the farmer's decisions and encouraging discussions among stakeholders on alternative management strategies.
\end{abstract}

Keywords: IWM; integrated weed management; decision support system; weed; Italian ryegrass; crop rotation; tillage system; sowing time

\section{Introduction}

Large areas of cereals are grown due to the need for cereal grain for fodder, flour and malting barley. By far, winter wheat is the most abundant crop in most European regions, with $44 \%$ of the harvested cereal crops being common wheat and spelt in 2018 [1]. In Denmark, the area with autumn-sown cereals was around $60 \%$ in 2019 , with winter wheat constituting $41 \%$ of the total [2]. Concern over production stability and environmental considerations have increased the focus on diversity and alternative management strategies [3,4]. The EU Sustainable Use Directive aims at reducing the risks of pesticide use to human health and the environment, by promoting integrated pest management (IPM), including alternative techniques and approaches (EU Framework Directive 2009/128/EC). Integrated weed management (IWM), as part of IPM, includes strategies that decrease the reliance on herbicides and optimally integrate measures for prevention of weed establishment, a reduction of crop interference and weed seed return [5].

Grass weeds are a group of weeds, which requires special attention, due to a substantial risk of yield losses and herbicide resistance development [6]. One of the main issues with many grass 
weed species is that their life cycle is more or less similar to that of winter wheat, hence they thrive in a cropping system with a high proportion of autumn-sown cereals. A continuous winter wheat cropping system with limited soil disturbance can therefore be considered a worst-case scenario for grass weed management. Decision support systems (DSS) can aid in the practical implementation of IWM, by visualising the long-term consequences of a certain crop rotation, including the benefits of diversification. Ideally, such DSS take into account yield, weed biology, the influence of cultural and mechanical management tactics and the goal of reduced herbicide use.

Several models have been developed with this aim as research models, but few have been adopted by farmers. One reason is that most models operate at a time scale of a single growing season [7], which inadequately reflects the long-term requirements of IWM. A second issue is that large numbers of parameter input are often required from the user, which reduces the usability for farmers and advisors. A third issue is that a DSS needs to include a diversity of tools in all the crops included in the rotation, to be relevant for IWM. Often, a DSS aims at decisions related to a specific weed management tool, like herbicide choice [8,9]. A last barrier for widespread uptake of DSS is that farmers have different preferences for the outcome of decision support systems and the level of detail required. A sociological survey on the use of a DSS in Denmark concluded that farmers could be assigned to three major groups characterised by different approaches to decision making and preferences for DSS [10]. The three groups were system-oriented farmers, experience-based farmers and advisory-oriented farmers. The system-oriented farmers was the group considered most likely to benefit from a DSS, as the other two groups either base their decision primarily on own experiences or advisory services. The system-oriented farmer will aim for long-term assessments and search for generalised scientific knowledge.

Very few DSS have been published that follow IWM recommendations for diverse strategies. One such example is the Australian DSS for Integrated Ryegrass Management, RIM [11]. RIM aims to provide practical advice and the visualisation of the long-term development of Lolium rigidum (Gaud.), rigid ryegrass, populations [11-13]. It was developed for the management of L. rigidum in the Western Australian wheatbelt, and the concept has subsequently been modified and adapted for several weed species and cropping systems, including the Southern Australian wheatbelt, Papaver rhoeas (L.), common poppy, in Spanish cereal fields and Echinochloa crus-galli, cockspur, complex in Philippines rice systems [14-16]. RIM is different from many DSS, as the intent is to visualise the tendencies in L. rigidum development and the economic consequences over a long time period, rather than providing specific recommendations for immediate actions. RIM can help understand the long-term consequences of strategy choices, with the most relevant scenarios depending on the farmer's situation and experience. In Australia, the main objective for the development of RIM was herbicide resistance management. Lacoste et al. [13] investigated nine different scenarios in RIM, with a focus on loss of certain modes of action, delayed sowing time, harvest seed destruction and initial L. rigidum density; which demonstrated how management practices can influence the financial costs of herbicide resistance.

RIM was chosen for adaption to Danish conditions for Lolium multiflorum (Lam.), Italian ryegrass, management, as it was evaluated as suitable for general advice on diversification in cropping systems. Furthermore, documentation was already available for integration with advisory services [17]. L. multiflorum is one of the most important grass weeds in Denmark, and resistance development has accelerated in recent years $[18,19]$. Furthermore, L. multiflorum can be considered representative for other annual grass weeds in Northern Europe, for which the integrated management strategies are, to some extent, applicable.

The objective of this paper was to describe the adjustments made to RIM for Danish cereal cropping systems, based on the most relevant IWM principles and the associated challenges in Denmark. In order to show the usefulness of DK-RIM (Denmark-Ryegrass Integrated Management), the influence of diverse crop rotations and tillage practice on L. multiflorum development was evaluated, by running scenarios with different levels of crop rotation diversity and tillage intensity. 


\section{Materials and Methods}

\subsection{Lolium multiflorum (Lam.), Italian Ryegrass}

L. multiflorum is primarily an annual grass, but biannual and perennial varieties also exist. The annual variety can mature and shed seeds in both autumn- and spring-sown crops, while the perennial varieties of L. multiflorum do not usually shed seeds in spring-sown crops. The annual variety is the most common; consequently, the model represents this latter form only. Plants of L. rigidum can yield more than 35,000 seeds per $\mathrm{m}^{2}$, and the same value was adopted for L. multiflorum, as no documentation was available for this species growing under field conditions [14]. There is a limited initial dormancy under Northern European conditions, which leads to a rapid germination of seeds left on the soil surface under moist conditions. Once buried, the seeds survive longer, but most seeds lose the ability to germinate after 3 years [20]. Like most other annual grass weeds, L. multiflorum is mainly a problem in crop rotations dominated by autumn-sown cereals under Northern European conditions. The cultural control management practices for L. multiflorum, generally, match those for other annual grass weeds; (i) late sowing in autumn, (ii) increased spring crop frequency in the crop rotation plus inclusion of perennial crops, like grasses grown as seed crops or pasture, (iii) increased crop seeding density, (iv) awareness at harvest to limit the spread of seeds by machinery, and (v) leaving the seed on the soil surface longer after harvest.

\subsection{Model Overview}

DK-RIM shows the likely outcome of selected management practices on populations of L. multiflorum. The strength of the DSS lies in the visualisation of the long-term consequences of management choices relative to other management strategies, rather than actual recommendations, and it should not be considered as an economic planning tool. Structure, functionalities and important assumptions of RIM were described by Lacoste and Powles [11,13]. The simplifications made in the original Australian RIM were carried over; hence, no yearly climatic variation and no spatial heterogeneity were included [13]. DK-RIM simulates the biology of L. multiflorum plant populations, which in turn affects the size of the soil seed bank with consideration of seed germination patterns, natural seed mortality and dormancy. Management practices and crop competition affect the emerged L. multiflorum plants, and successful control tactics reduce the healthy proportion of L. multiflorum plants, with a resulting lower seed production. Beside L. multiflorum seed production, the management practices affect yield and economics through a rule-based model dependent on the timing and the combination of practices in a 10-year strategy (Figure 1).

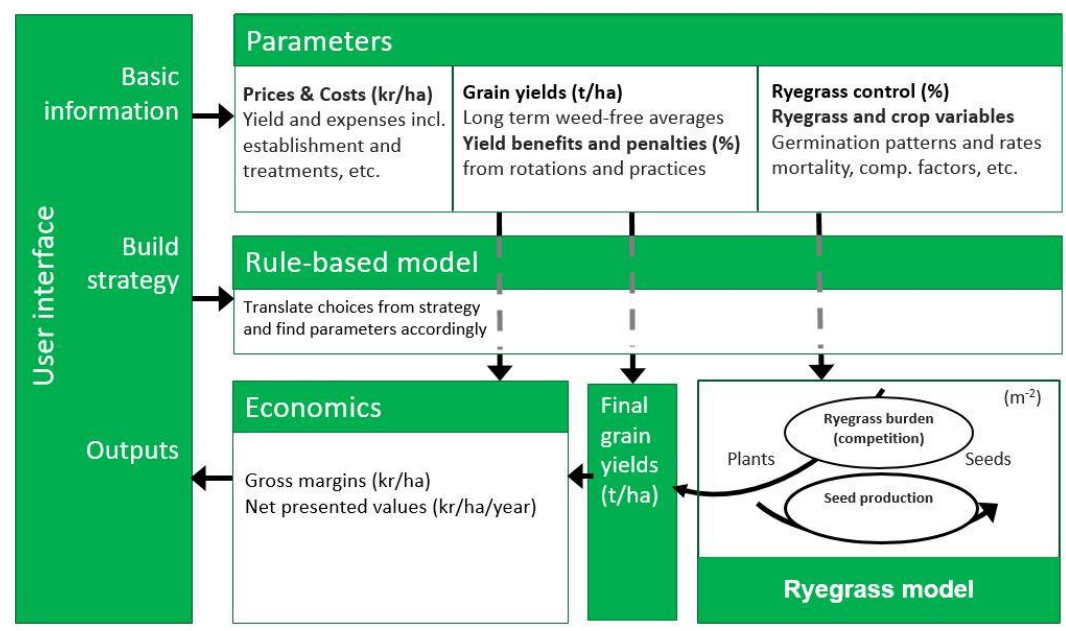

Figure 1. The structure of DK-RIM (Denmark-Ryegrass Integrated Management) showing the interconnections of the rule-based model, the L. multiflorum (Italian ryegrass) model and the economic output (modified from [11]). kr: Danish kroner. 
Differences from the original RIM mainly include differences in cropping systems and parameter estimates, which were adapted to reflect $L$. multiflorum behaviour in the Northern European region. The most significant of these modifications was adjustment to the growing season from semi-arid Australia (one winter crop a year, summer in fallow) to that of northern Europe, with both autumnand spring-sown crops. In addition, cover crops established between cash crops can be included in DK-RIM. Harvest seed destruction is not included, even though it can be an effective measure to control L. multiflorum, but it has limited relevance in Denmark, as the burning of plant material in fields is not allowed, and seed destruction tools have not gained attention by Danish farmers. Another modification was the removal of animal husbandry, which only influenced the economic evaluation, not the biological evaluations.

To implement the cropping system under Northern European conditions, the yearly crop cycle was divided into autumn- and spring-sown crop cycles. If an autumn-sown crop is chosen, the spring sowing cycle is not activated and vice versa. There are three sowing timings available for both seasons; early (autumn before 15th Sep., spring before 20th Mar.), normal/intermediate (autumn 1st-15th Sep., spring 20th Mar.-15th Apr.), and late (autumn after 20th Sep., spring after 15th Apr.) Delayed sowing implies a need for higher seeding rates to ensure the optimal tiller number per area. When the winter cereals are sown late, the individual plants will result in fewer tillers and therefore an increased number of plants is required to reach the same number of tillers as for earlier sowing. If the user chooses a high seeding rate with early sowing, the resulting plant number will be higher, and hence a higher tiller number per area is achieved. The autumn and spring crop cycles are similar with regard to cultivation choices, but for the autumn-sown crops, there are additional choices for pre-emergence and post-emergence herbicide applications, before going through the winter growth pause and continuing on to the possible post-emergence spring application of herbicides. Glyphosate application before crop establishment is available for all sowing times and crops, as the only non-selective herbicide option in Denmark. In addition to the cash crops included in the model (Table 1), grass and a grass/clover mix are included as possible breaks in the cropping sequence, which can be used to control heavy infestations of L. multiflorum, but without an economic outcome.

\subsection{Input Parameters and User Interface}

DK-RIM was implemented in Microsoft Excel@(Version 2016 for Microsoft Windows) and is available for farmers and advisors via a publicly available webpage at a national advisory service centre [21]. Two modes are accessible for DK-RIM, locked and unlocked. In the locked mode, the user will experience software-like behaviour (implemented in Visual Basic for Application macros, VBA 7.1, 2012, Microsoft). In the unlocked mode, the programme makes all content visible and editable. For new users, a tutorial is available as part of the programme.

The parameters varying most among farms can be adjusted in the user interface, to accommodate local and yearly variations, most notably potential weed free yield and commodity sales prices. The herbicide control options available and initial size of the L. multiflorum population are adjusted by the user from the "Basic information" page. There are additional layers of adjustable options regarding prices and management practices, which the user can access ("More prices" and "More options"). Generally, these parameters are related to specific practices at farm level, and once they are adjusted to the actual situation on the farm, the farmer does not need to adjust them again, unless practices change. The following step is "Build Strategy", where the crop rotation and management practices are selected. The output pages show a number of graphs and tables to visualise and compare the planned strategies. These results can be exported for further use.

Herbicide options are often restricted in DSS to reflect legislative imperatives, but in DK-RIM, the assumption is made that the farmers are aware of the limitations on herbicide use (including the legal application time and dose) and respect these constraints. Herbicide resistance is one of the main factors driving the need for long-term strategies and integrated weed management. Resistance evolution, however, is not modelled in DK-RIM. Instead, the user specifies whether the included herbicides are 
still effective, and at what level of efficacy. In the DSS, all L. multiflorum plants are assumed to be equally susceptible to herbicides; thus, the selection for resistant biotypes is not included in the model.

To ensure its relevance and user friendliness, DK-RIM was presented and discussed at a workshop, with five independent advisors from different regions of Denmark. The advisors were asked to test the model with different scenarios relevant to their region. These ranged from traditional ploughed strategies to no-till strategies on different soil types and with different sizes of L. multiflorum populations. Their feedback led to several adjustments and substantial improvement of DK-RIM. Furthermore, DK-RIM was presented at a farmer workshop organised by an advisor service, in a region with severe L. multiflorum problems, and the farmers gave their immediate feedback.

\subsection{The L. multiflorum Population Model in DK-RIM}

The number of L. multiflorum plants emerging at the time of sowing is calculated by multiplying the number of seeds in the soil by the germination percentage. If sowing is postponed, a larger number of seeds will have emerged, and are thus controlled by the seed bed preparation. The emergence pattern is affected by tillage system and timing. At any given sowing time, the number of live germinated L. multiflorum plants $\left(G_{\text {time }}\right)$ is found by (Equation (1)).

$$
G_{\text {time }}=G_{\text {time-1 }} \times R S_{\text {time- } 1}+R_{\text {time-1 }} \times V S_{\text {time }}
$$

where $G_{\text {time-1 }}$ is the number of germinated L. multiflorum plants in the period before, $R S_{\text {time- } 1}$ is the number of L. multiflorum plants surviving the period before, $R_{\text {time- } 1}$ is the number of viable seeds remaining in the soil and $V S_{\text {time }}$ is the percentage of viable seeds that germinate in the present period. The number of L. multiflorum plants at the end of the growing season is affected by management practices, including herbicide applications, cover crops and other options, as specified by the user. Herbicide applications, either pre-emergence or post-emergence, will modify this equation by a factor, depending on the herbicide efficacy.

The L. multiflorum seed population in the soil is modified by the number of seeds germinating through the growth season, by subtracting the germinated number. The L. multiflorum seed set $\left(R_{\text {set }}\right)$ is modified by the control measures applied during the season, additional emerged L. multiflorum plants, and the natural mortality. For further details, see the reference manual for RIM [22]. The effect of interand intraspecific competition from autumn- and spring sown crops (Table 1) and L. multiflorum and sub-lethal herbicide effects on the L. multiflorum seed set per plant $\left(R_{\text {set }}\right)$ are described by the following equation, adopted from Renton et al. [23] (Equation (2)).

$$
R_{\text {set }}=R_{\max } \times\left(\frac{\mathrm{r} \times W_{H}}{1+r \times W_{H}+c \times D}\right) \times s
$$

When the crop is grass or grass with clover the equation is alternatively modified to (Equation (3)).

$$
R_{\text {set }}=R_{\max } \times\left(\frac{1}{1 \times W_{H} \times f}\right) \times s
$$

where $R_{\max }$ is the maximum number of seeds produced per $\mathrm{m}^{2}$ per year in a non-competitive situation, $r$ is the intraspecific competition factor for L. multiflorum, $W_{H}$ is the healthy equivalent L. multiflorum plants surviving the season, $c$ is the interspecific crop competition factor, $D$ is the crop density, $s$ is the phytotoxic effect of any applied herbicides, and $f$ is the competition factor of pasture (Table 2).

$W_{H}$ is calculated as a percentage of the potential plant number, based on the potential for seed production relative to sowing time, the germination and control percentage (Equation (4)). For grass and grass clover, this is an expert assessment, as the seeding density of grass cannot be adjusted by the user. Both the equation for L. multiflorum seed set $\left(R_{\text {set }}\right)$ and the healthy equivalent plants $\left(W_{H}\right)$ were modified compared to the original RIM. 


$$
W_{H}=G_{\text {time }} \times R_{\text {control }} \times p
$$

where $G_{\text {time }}$ is the germinated number of L. multiflorum plants at a given time, $R_{\text {control }}$ is the percentage L. multiflorum plants controlled in the given period, and $p$ is the progeny index, representing the number of seeds produced per plant, relative to the maximum possible amount, which is affected by sowing time.

Table 1. List of cash crops implemented in DK-RIM, with corresponding competition factors (c) used in Equation (2) and maximum values for yield loss (a) used in Equation (5).

\begin{tabular}{|c|c|c|}
\hline $\begin{array}{c}\text { Cash Crops Implemented in } \\
\text { DK-RIM }\end{array}$ & $\begin{array}{c}\text { Interspecific Crop Competition } \\
\text { Factor }(c)[23,24]\end{array}$ & $\begin{array}{c}\text { Max Yield Loss from } \\
\text { L. multiflorum }(a)(\%)[24-26]\end{array}$ \\
\hline Winter wheat & 0.09 & 60 \\
\hline Winter barley & 0.15 & 60 \\
\hline Winter rye & 0.09 & 60 \\
\hline Spring barley & 0.25 & 45 \\
\hline Spring oat & 0.3 & 40 \\
\hline Spring wheat & 0.2 & 40 \\
\hline Winter oilseed rape & 0.2 & 45 \\
\hline Legumes (default peas) & 0.07 & 95 \\
\hline
\end{tabular}

Table 2. List of Lolium multiflorum parameters used in DK-RIM ${ }^{1}$.

\begin{tabular}{lclc}
\hline $\begin{array}{l}\text { Intraspecific competition factor for } \\
\text { L. multiflorum }(r) \text { [23] }\end{array}$ & 0.04 & $\begin{array}{l}\text { Extra mortality of seeds in soil with } \\
\text { need-based ploughing }\end{array}$ & $80 \%$ \\
\hline $\begin{array}{l}\text { Competition factor of pasture on } \\
\text { L. multiflorum }(f)\end{array}$ & $99 \%$ & $\begin{array}{l}\text { Sub-lethal effect of post-emergence } \\
\text { herbicides on viability of seeds }(s) \text { [27] }\end{array}$ & $33 \%$ \\
\hline $\begin{array}{l}\text { Natural mortality of seeds during } \\
\text { season [27] }\end{array}$ & $30 \%$ & $\begin{array}{l}\text { L. multiflorum germination in grass or } \\
\text { grass-clover crops }\end{array}$ & $30 \%$ \\
\hline Natural mortality of seedlings [27] & $5 \%$ & Removal of seeds with crop at harvest [27] & $5 \%$ \\
\hline 1 When no reference is stated the parameter is an expert asessment for L multiflorum under Danish conditions.
\end{tabular}

Some parameters in DK-RIM were adjusted for L. multiflorum according to literature or expert assessments (Table 2), but if no documentation was available, parameters for L. rigidum was used.

\subsection{Yield Loss}

The maximum weed free yield is modified by the L. multiflorum competition and the benefits and penalties arising from the selected crop rotation.

Yield loss due to competition is described by (Equation (5)).

$$
Y_{\text {loss }}=\frac{i \times D_{\text {ryegrass }}}{1+\left(\frac{i \times D_{\text {ryegrass }}}{a}\right)}
$$

where $i$ describes the \% yield loss per L. multiflorum plant per unit area as weed density approaches zero and was $1 \%$ for all crops, $a$ is the maximum yield loss in each specific crop (Table 1 ) and $D$ is the density of L. multiflorum plants per unit area at the end of the season [28].

\subsection{Management Tools}

The management tools available in DK-RIM include crop rotation sequences with or without cover crops, alternate tillage and establishment practices, plus herbicide applications. Few other options are available in Denmark to supplement these management options. Desiccation before harvest does not provide significant control of L. multiflorum, as most of the seeds are mature and shed before 
such desiccation. As a last resort with weed heavy infestations, the crop can be sacrificed to prevent L. multiflorum reaching maturity. Mechanical weed control is not included in DK-RIM.

\subsubsection{Crop Rotations}

Weed germination and subsequent seedset can be reduced through increased crop diversity, e.g., by introducing more spring-sown crops [29-31], as only a few L. multiflorum plants will emerge in spring. By introducing more crop species, a diversification of herbicides is possible as well, which reduces the risk of resistance development, by introducing more modes of action. There are also yield effects of the crop rotation, as certain sequences are beneficial for productivity, while others will impose a cost through yield reduction. There is a general benefit of a leguminous pre-crop, of winter cereals following a spring crop and of oilseed rape following grass or grass/clover. On the other hand, there are penalties for immediately repeating crops, which is most pronounced for oilseed rape and legumes, whereas the yield penalty for wheat monoculture is highest in the first two years and then gradually diminishes. In DK-RIM, the benefits and penalties for each crop rotation are mainly controlled by parameters hidden from the user, but a few specific values are adjustable from the user interface. This is applicable for benefits after legumes and cover/catch crops, and for the penalties for repeating oilseed rape or legumes in the crop rotation. Legumes are a broad category, and the user has to adjust the benefit and penalties depending on the actual crop, as some legumes are more sensitive to repeated cropping than others. Colbach et al. [32] found that simulating varying affects in cropping systems showed larger effects over 5-10 years compared to 15-19 years, and that the longer that an individual tactic was used, the larger the impact was. The time span of 10 years in DK-RIM is considered appropriate to show the long-term effects of alternating management practices.

\subsubsection{Cover Crops}

A certain area with cover crops is mandatory for Danish farmers every season, which does not relate to weed management, but rather to legislation affecting nitrogen leaching. The level of weed suppression from cover crops is not well established and depends on the type of cover crops and the establishment timing plus the method of removal [33-35]. Gerhards and Schappert [36] discussed cover crop use in IWM and reported high control levels on volunteer cereals and other weeds. They attributed this partly to competition, and partly to allelopathic effects depending on the type of cover crop or mulches. Cover crops are included in DK-RIM as an optional management practice for farmers, with the level of control adjusted in the user interface.

\subsubsection{Cultivation Practices}

Mouldboard ploughing is an effective tool in grass weed control. Inversion tillage prevents establishment by killing a large proportion of newly emerged L. multiflorum plants. Ploughing will bury many seeds in a deeper soil layer, which will prevent immediate germination [37]. The timing of soil tillage is important, as seeds left on the soil surface will degrade faster than seeds buried. The efficacy of leaving seeds at the soil surface depends on the weed species, but is significant for L. multiflorum $[38,39]$.

The effect of soil tillage on L. multiflorum germination is adjustable in the user interface, where the user can choose to modify the level of weed control provided by ploughing, reduced tillage and no-till. Reduced tillage here represents a reduced tillage practice before every crop, which only disturbs the upper soil layer. Ploughing and no-till will have relatively stable effects on germination, but reduced tillage practice is a highly variable practice, and it does not cover the same type of soil management for all farmers. If farmers apply reduced tillage, it is important to adjust the control level for the practice accordingly, as the default "reduced tillage" is unspecified. In addition, DK-RIM offers the possibility for need-based ploughing, which is a practice used occasionally by some no-till farmers for increased weed control; typically, once every fourth to fifth year. This will bury the weed seeds in the deeper soil layers, and for seeds with short survival, it will kill the seeds before the next ploughing event. 
Furthermore, crop density and sowing time can be adjusted, which can also contribute to prevent emergence and control weed populations [29,40-42].

\subsubsection{Herbicide Application}

Herbicides are an important tool in L. multiflorum control, but preventive tactics and alternative weed measures must be in place before deciding to apply herbicides. The available herbicides are added by the user in three categories; pre-establishment, pre- and post-emergence with respective levels of efficacy. In Denmark, the only available pre-establishment herbicide is glyphosate, and therefore this was specifically included. Herbicide application will reduce the number of L. multiflorum plants establishing or reaching maturity and limit the seed production, depending on application timing.

\subsection{Economics}

The costs are implemented based on agricultural contractor prices, as this is the most common practice for small to medium farm sizes in Denmark. Machinery running expenses and payments are not modelled. Costs are included and subtracted from the yield income, which is simply obtained by multiplying crop yield with sales price for the commodity. EU agricultural subsidies are an important source of income, but the size of the EU subsidy varies over years and depends on a range of factors; the adjustments, however, cannot be described by equations, hence an average subsidy can be included from the user interface.

\subsection{Scenarios for Evaluation}

The aim of the six scenarios in this study was to evaluate the influence of crop rotation and tillage strategy on L. multiflorum development in the model. Even though a monoculture of winter wheat is not very common in Denmark, this was chosen as a standard scenario, to show the influence of increasing diversity in crop rotations (Table 3). A typical herbicide programme in winter wheat will consist of a pre-emergence herbicide, followed by an autumn and/or spring post-emergence herbicide. The optimal herbicide choice depends on sowing time and the emerged weed population. With a non-resistant L. multiflorum population, the full spraying programme will keep a L. multiflorum population under control at the short-term, and it would not be possible to see the effects of the IWM tactics in the results of the simulations. Therefore, only a pre-emergence herbicide application for L. multiflorum control was included in the scenarios. In all other crops, a commonly used herbicide programme is applied (Table 4). A starting population of twenty L. multiflorum plants per $\mathrm{m}^{2}$ the year before the simulations and a soil seed bank of fifty viable seeds per $\mathrm{m}^{2}$ were used.

Table 3. Scenarios included in the evaluation. Wheat and oilseed rape are winter crops, while barley is a spring crop.

\begin{tabular}{|c|c|c|c|}
\hline Scenario & $\begin{array}{l}\text { 4-Year Crop Rotation, } \\
\text { Repeated over } 10 \text { Years }\end{array}$ & Winter Wheat Cultivation Facts ${ }^{1}$ & $\begin{array}{l}\text { Scenaric } \\
\text { Results }\end{array}$ \\
\hline 1 & Wheat-Wheat-Wheat-Wheat & $\begin{array}{l}\text { Plough, early sown, standard density, } \\
\text { prosulfocarb }\end{array}$ & Figure 2 \\
\hline 2 & Wheat-Wheat-Wheat-Wheat & Plough, late sown, high density, prosulfocarb & Figure 2 \\
\hline 3 & Barley-Wheat-Wheat-Wheat & Plough, late sown, high density, prosulfocarb & Figure 2 \\
\hline 4 & Barley-Oilseed rape-Wheat-Wheat & Plough, late sown, high density, prosulfocarb & Figure 2 \\
\hline 5 & Wheat-Wheat-Wheat-Wheat & $\begin{array}{l}\text { Reduced tillage, early sown, standard density, } \\
\text { prosulfocarb }\end{array}$ & Figure 3 \\
\hline 6 & Wheat-Wheat-Wheat-Wheat & $\begin{array}{l}\text { No-till, early sown, standard density, } \\
\text { prosulfocarb }\end{array}$ & Figure 3 \\
\hline
\end{tabular}

\footnotetext{
${ }^{1}$ Prosulfocarb: Boxer, Syngenta Nordics A/S.
} 
Table 4. Crops and management options included in the scenarios.

\begin{tabular}{|c|c|c|c|c|}
\hline Crop & Sowing Time & $\begin{array}{l}\text { Seeding Density } \\
\text { (kg/ha) }\end{array}$ & Soil Tillage & Herbicide $^{1}$ \\
\hline Winter wheat & $\begin{array}{l}\text { Early: primo Sep. } \\
\text { Late: primo Oct. }\end{array}$ & $\begin{array}{l}\text { Standard } 100 \\
\text { High } 185\end{array}$ & $\begin{array}{l}\text { Ploughed + harrow seedbed } \\
\text { preparation } \\
\text { Reduced tillage: superficial soil } \\
\text { disturbing once } \\
\text { No-till: direct sowing, no soil } \\
\text { disturbance }\end{array}$ & $\begin{array}{l}1600 \mathrm{~g} \text { prosulfocarb per ha, } \\
\text { pre-emergence }\end{array}$ \\
\hline Spring barley & April & 190 & $\begin{array}{l}\text { Spring ploughed }+ \text { harrow seedbed } \\
\text { preparation }\end{array}$ & $\begin{array}{l}3.5 \mathrm{~g} \text { iodosulfuron }+ \\
0.525 \mathrm{~g} \text { mesosulfuron per } \\
\text { ha, post-emergence }\end{array}$ \\
\hline Winter oilseed rape & Ultimo August & 4.5 & $\begin{array}{l}\text { Ploughed }+ \text { harrow seedbed } \\
\text { preparation }\end{array}$ & $\begin{array}{l}500 \mathrm{~g} \text { propyzamide per ha, } \\
\text { post-emergence }\end{array}$ \\
\hline
\end{tabular}

\section{Results}

Different scenarios with alternate crop rotations; different sowing time and soil tillage options resulted in marked changes in number of mature L. multiflorum plants at the end of growing seasons and seeds in soil at the start of the following season.

\subsection{Crop Rotation and Delayed Sowing}

Delaying sowing (scenario 2) had a marked effect on the number of mature L. multiflorum plants over 10 years ( $48 \%$ less plants compared to scenario 1), and the number of seeds in the soil at the start of each season was also reduced ( $6 \%$ less seeds), but it was still high and increased over the 10 years (Figure 2). Changing the crop rotation to a four-year rotation with spring barley as the first crop (scenario 3) and further adding an oilseed rape crop in the rotation (scenario 4) reduced weed numbers and kept the L. multiflorum population under relative control, even after 10 years. In scenario 3, the number of mature L. multiflorum plants were $59 \%$ lower than in scenario 2, and further reduced by $49 \%$ in scenario 4 . This is an overall reduction of $89 \%$ after 10 years, compared to the continuous wheat rotation in scenario 1 . After 10 years of scenario 4 , the number of mature L. multiflorum plants per $\mathrm{m}^{2}$ shedding seeds and adding to the soil seed bank was 197 plants, with approximately 6000 seeds in the soil.

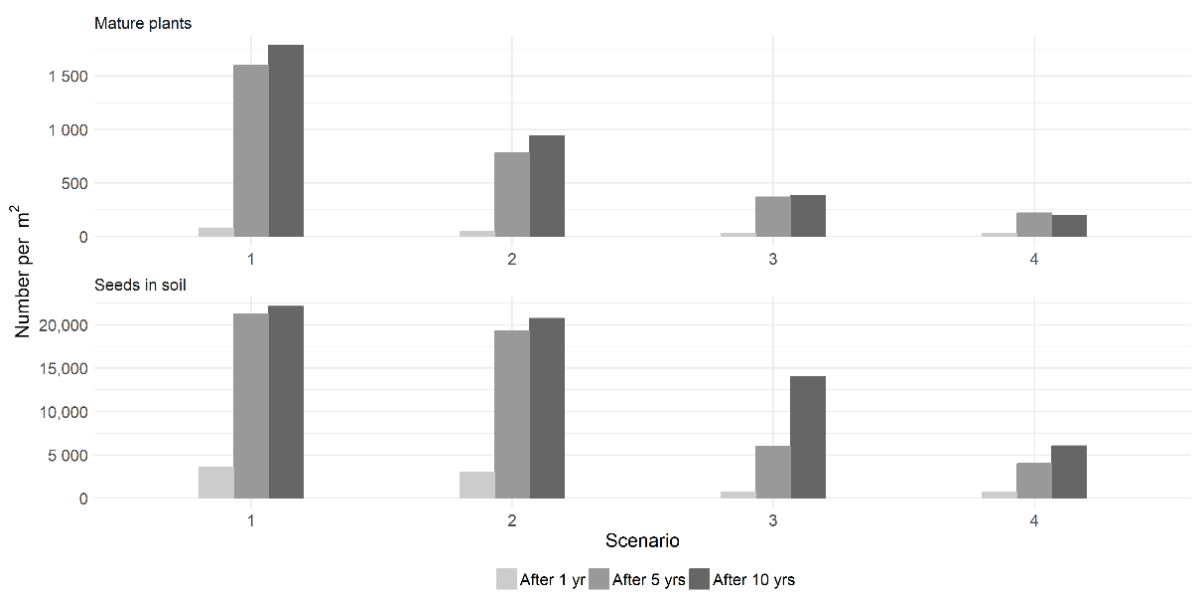

Figure 2. Number of mature L. multiflorum plants per $\mathrm{m}^{2}$ at the end of the three periods (top) and number of seeds in the soil per $\mathrm{m}^{2}$ at the beginning of the following season (bottom) in the simulations with increasing diversity in the four-year crop rotation (Table 3). Scenario 1 represent a ploughed mono-wheat scenario with early sowing. Scenario 2 was the same with late sowing. Scenario 3 starts the 4-year rotation with spring barley and in scenario 4 the rotation is spring barley, winter oilseed rape, winter wheat, winter wheat. 


\subsection{Tillage System}

Changes in the soil tillage strategy were also compared to scenario 1, with less soil disturbance in terms of a reduced tillage system (scenario 5) and a no tillage system (scenario 6) (Figure 3). To observe the effect of changing soil tillage system, the rest of the factors were maintained as in the reference scenario (scenario 1). Ploughing has the largest control effect on L. multiflorum and changing to a reduced tillage system increased the number of mature L. multiflorum plants after 10 years ( $32 \%$ more plants compared to the ploughed strategy) and led to increased L. multiflorum infestations (Figure 3). In the no-till scenario, the number of mature L. multiflorum was also increased compared to the ploughed scenario ( $20 \%$ more plants) after a 10 -year simulation. The number of seeds in the soil was less affected by the soil tillage strategy than mature plants ( $12 \%$ more seeds in the reduced tillage strategy), while the percentage change in seeds for the no tillage strategy compared to the ploughed strategy was similar (19\% more seeds).

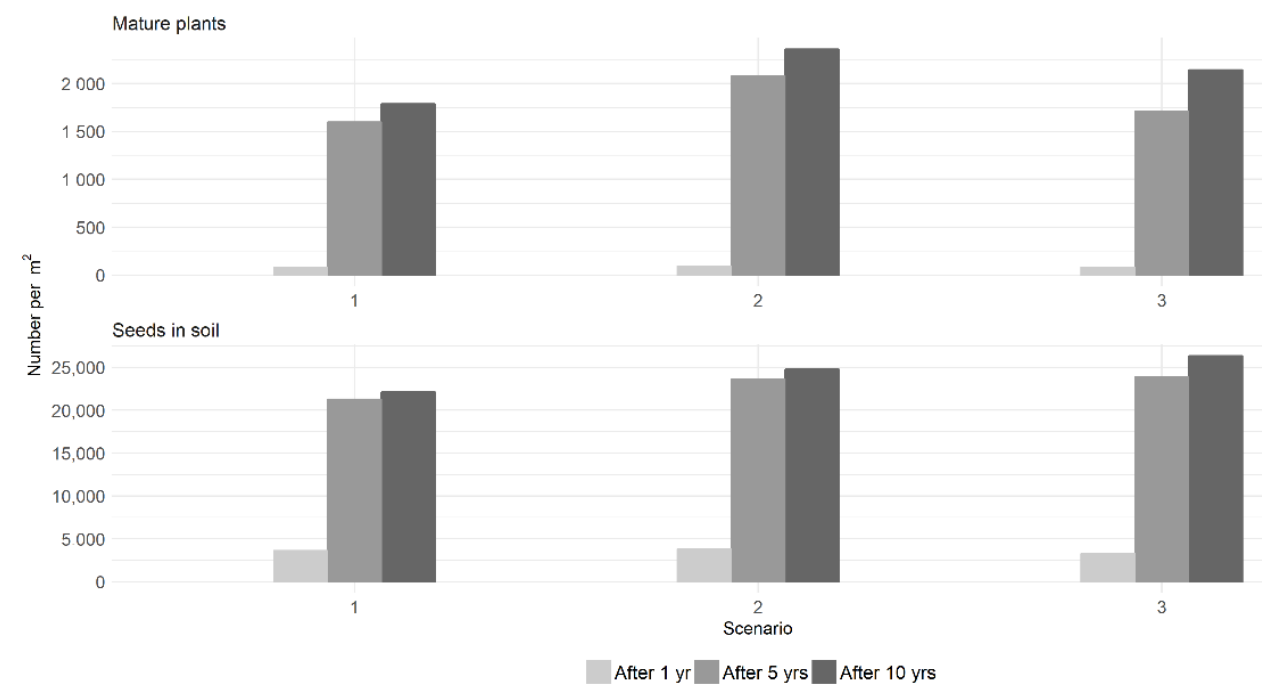

Figure 3. Number of mature L. multiflorum plants per $\mathrm{m}^{2}$ at the end of the three periods (top) and number of seeds in the soil per $\mathrm{m}^{2}$ at the beginning of the following season (bottom) in the simulations with different tillage strategies (Table 3). Scenario 1 represented a ploughed mono-wheat scenario with early sowing. Reduced tillage (scenario 5) represented any tillage strategy with only superficial soil inversion, whereas no-till (scenario 6) is a true no-till strategy with direct sowing.

\section{Discussion}

The delayed sowing of winter wheat and the increased diversity in crop rotations are common advice to manage grass weeds [29]. The simulations reflected this, as a better control of L. multiflorum was obtained when these control options were implemented in a typical ploughed system. In the scenarios, the limited inclusion of herbicides in the winter wheat crop enabled insights into the model behaviour with alternate cultural tactics in L. multiflorum management. In a situation without resistance, the cultural tactics and a basic herbicide application were observed to keep L. multiflorum at relatively low levels (scenario 4), but still at a level which will be unacceptable farmers. Even with the diverse crop rotation, a herbicide programme, including post-emergence application, will be necessary. Continuous winter wheat or a low-diversity crop rotation may appear attractive to farmers in the short term, as there are no immediate, unsolvable weed problems, and the commodity is easy to sell with profit, even with a minor yield penalty compared to mixed crop rotations [30,43]. Therefore, the implementation of IWM, including crop rotation changes, is often driven by necessity caused by loss of herbicide efficacy [44]. The implementation of diversity in the crop rotation depends on the farmer's ability to sell other commodities and the soil suitability for other crops. However, the crop rotation does not need to be fixed in the long term to obtain the benefits of crop diversification; farmers may as well have an overall aim for the crop rotation, but allow for changes through time. Planning 
on a long-term basis may infer suboptimal economic results in the short term. Thus, the trade-off between immediate economic surplus and the possible detrimental long-term effects of current practice needs to be a part of the management strategy for both advisors and farmers [45]. The rotation shown in scenario 4 could be further diversified with a longer rotation, and potentially include a grass or grass/clover leys. Grass or grass/clover leys over two to three years with regular mowing will reduce grass weed problems, but will be costly for the farmer if no economic outcome can be established from the leys. A period of grass or grass/clover can be a relevant measure in fields with severe L. multiflorum problems. The perennial crop will keep the L. multiflorum seeds buried and deplete the soil seed bank through natural seed mortality, prior to reintroducing a crop rotation with annual crops [46].

Lower soil tillage intensity is becoming more and more common, as it protects and enhances a range of beneficial services in agricultural systems [47]. Conversion to no-till strategies have benefits in terms of reduced soil erosion, improved soil structure, reduced leaching and less run-off, but it also carries new challenges. In no-till systems, grass weeds have the opportunity to propagate and carry over from one cropping season to the next and accelerate grass weed problems [48-50]. In most no-till strategies, glyphosate is applied prior to establishment, either to remove all surviving weeds or to destroy a cover crop [49]. There is no application of glyphosate before crop establishment in the presented no-till scenario. It was omitted to enable a more direct comparison of tillage systems on the L. multiflorum population development. Comparison of the three tillage systems showed a difference among the systems, with ploughing being more effective in L. multiflorum control than no-till and reduced tillage. The no tillage strategy resulted in fewer mature L. multiflorum plants than the reduced tillage system, which is related to the germination pattern of the two systems. Farmers with no-till systems are reluctant to use ploughing as a control measure, and an occasional need-based ploughing will only be implemented when grass weed problems are out of control. Reduced tillage is a strategy, which does not have any of the advantages of ploughing or no-till for grass weed control; rather, it keeps the grass seeds in the topsoil and exposes the seeds every season to conditions favourable for germination [51]. As the type of reduced tillage is not specified in DK-RIM, this is highly dependent on the level of control stated by the user. There are, however, underlying dynamics in the model, which influence the outcome, which makes reduced tillage practices less viable for management of L. multiflorum than ploughing and no-till. As reduced tillage systems cover a broad variety of practices it is difficult to evaluate the model behaviour. In practice, variable control levels have been observed for reduced tillage systems [29].

The primary aim of the presented scenarios using DK-RIM was to show the DSS's relevance under Danish growing conditions, with the adjustments made to the original RIM. The scenario outcomes corresponded to results from literature and practical experience, in terms of the influence of sowing time, crop rotation and tillage strategy.

Crop rotation diversification was the single factor that had the highest effect on seed build-up of L. multiflorum in the scenarios. None of the tactics were expected to achieve adequate management of L. multiflorum on their own, whereas the combined effort of several tactics influenced populations substantially. Similar results have been observed for other grass weeds, such as L. rigidum [52], Apera spica-venti, loose silky-bent [51], and Avena fatua, common wild oat [53]. The present scenarios represented a situation devoid of $L$. multiflorum herbicide resistance, which might be unrealistic in many parts of Denmark [19]. In fields with resistance development, the cultural practices will become even more important. DK-RIM represents a cropping system, which is representative for several Northern European countries in the same climatic zone. Differences in the management practices among countries and regions exist, e.g., the availability of tools for seed destruction at harvest, but establishment practices and crop rotations are similar. A future adoption of DK-RIM in neighbouring regions is therefore feasible, with minor modifications for differences in management practices. For Danish conditions, there are additional features, which can be implemented to have a more complete DSS, e.g., alternate row distances, to incorporate mechanical weed control, mixed populations of susceptible and resistant L. multiflorum, or additional crops like grasses grown as seed crops. 
Experiences from Western Australia with the original RIM showed that the tool is a valuable starting point for discussions between farmers and advisors [54]. The first experiences from Denmark with farmers meetings on L. multiflorum management presenting DK-RIM were generally positive, and indicated that it is a valuable practical tool, when farmers use it in cooperation with advisors. The main purpose of DK-RIM should be to generate discussion cf. the recommendations of Lacoste and Powles [17]. A few farmers were enthusiastic, and they might gain from independent use. Other farmers, who rely on advisors to plan their management, are more likely to benefit from the workshop approach. Involving stakeholders in the development of a DSS is essential, and even though complex models might provide the most accurate predictions of management consequences, they may be of little value in practical planning [55]. More targeted communication from the advisory services and researchers have been identified as a stepping stone on the road to an increased implementation of IWM [56,57] and IPM in general [58], and a DSS like DK-RIM can aid this type of communication.

\section{Conclusions}

DK-RIM provided practical relevant decision support under Danish conditions for the management of L. multiflorum. The DSS was evaluated by advisors and farmers, who found it a valuable tool to visualise the long-term consequences of different management strategies. The scenarios showed that an increased diversity in the crop rotation and to a minor extent, delayed sowing of winter wheat, were tactics that reduced the impact of L. multiflorum.

Author Contributions: Conceptualization and methodology, M.S., M.L. and J.E.J.; software, M.S., M.L., G.J.S. and N.H.; writing_-original draft preparation, M.S.; writing—review and editing, G.J.S., M.L., J.E.J., N.H.; project administration, M.S.; funding acquisition, M.S. All authors have read and agreed to the published version of the manuscript.

Funding: This research was funded by Promilleafgiftsfonden for Landbrug (Fund for developing the agricultural sector) in Denmark (2017-2018), Project name: “Værktøj til planlægning af græsukrudtsbekæmpelse (DK-RIM)/Tool for planning of grass weed management (DK-RIM)".

Acknowledgments: The authors acknowledge the support from five agricultural advisors, who tested and commented on the first version of the DK-RIM.

Conflicts of Interest: The authors declare no conflict of interest. The funders had no role in the design of the study; in the development of the DSS; in the writing of the manuscript, or in the decision to publish the results.

\section{References}

1. Eurostat. Agricultural Production-Crops. Available online: https://ec.europa.eu/eurostat/statisticsexplained/index.php?title=Agricultural_production_-_crops\#Cereals (accessed on 1 May 2020).

2. Denmark, S. Vinterafgrøderne er i Fremgang i 2019. Available online: https://www.dst.dk/da/Statistik/nyt/ NytHtml?cid=28626 (accessed on 1 May 2020).

3. Barzman, M.; Barberi, P.; Birch, A.N.E.; Boonekamp, P.; Dachbrodt-Saaydeh, S.; Graf, B.; Hommel, B.; Jensen, J.E.; Kiss, J.; Kudsk, P.; et al. Eight principles of integrated pest management. Agron. Sustain. Dev. 2015, 35, 1199-1215. [CrossRef]

4. Lamichhane, J.R.; Devos, Y.; Beckie, H.J.; Owen, M.D.K.; Tillie, P.; Messean, A.; Kudsk, P. Integrated weed management systems with herbicide-tolerant crops in the European Union: Lessons learnt from home and abroad. Crit. Rev. Biotechnol. 2017, 37, 459-475. [CrossRef] [PubMed]

5. Buhler, D.D. Challenges and opportunities for integrated weed management. Weed Sci. 2002, 50, $273-280$. [CrossRef]

6. Powles, S.B.; Yu, Q. Evolution in action: Plants resistant to herbicides. In Annual Review of Plant Biology; Merchant, S., Briggs, W.R., Ort, D., Eds.; Annual Reviews: Palo Alto, CA, USA, 2010; Volume 61, pp. 317-347.

7. Holst, N.; Rasmussen, I.A.; Bastiaans, L. Field weed population dynamics: A review of model approaches and applications. Weed Res. 2007, 47, 1-14. [CrossRef]

8. Ford, A.J.; Dotray, P.A.; Keeling, J.W.; Wilkerson, J.B.; Wilcut, J.W.; Gilbert, L.V. Site-Specific Weed Management in Cotton Using WebHADSS (TM). Weed Technol. 2011, 25, 107-112. [CrossRef] 
9. Sønderskov, M.; Rydahl, P.; Bøjer, O.M.; Jensen, J.E.; Kudsk, P. Crop protection online-weeds: A case study for agricultural decision support systems. In Real World Decision Support Systems -Case Studies; Papathanasiou, J., Ploskas, N., Linden, I., Eds.; Springer: Cham, Switzerland, 2016; Volume 37, pp. 303-320.

10. Jørgensen, L.N.; Noe, E.; Langvad, A.M.; Jensen, J.E.; Ørum, J.E.; Rydahl, P. Decision support systems: Barriers and farmers' need for support. Bull. OEPP/EPPO Bull. 2007, 37, 374-377. [CrossRef]

11. Lacoste, M.; Powles, S. RIM: Anatomy of a Weed Management Decision Support System for Adaptation and Wider Application. Weed Sci. 2015, 63, 676-689. [CrossRef]

12. Pannell, D.J.; Stewart, V.; Bennett, A.; Monjardino, M.; Schmidt, C.; Powles, S.B. RIM: A bioeconomic model for integrated weed management of Lolium rigidum in Western Australia. Agric. Syst. 2004, 79, 305-325. [CrossRef]

13. Lacoste, M.; Powles, S. Upgrading the RIM Model for Improved Support of Integrated Weed Management Extension Efforts in Cropping Systems. Weed Technol. 2014, 28, 703-720. [CrossRef]

14. Monjardino, M.; Pannell, D.J.; Powles, S.B. Multispecies resistance and integrated management: A bioeconomic model for integrated management of rigid ryegrass (Lolium rigidum) and wild radish (Raphanus raphanistrum). Weed Sci. 2003, 51, 798-809. [CrossRef]

15. Torra, J.; Cirujeda, A.; Recasens, J.; Taberner, A.; Powles, S.B. PIM (Poppy Integrated Management): A bio-economic decision support model for the management of Papaver rhoeas in rain-fed cropping systems. Weed Res. 2010, 50, 127-139. [CrossRef]

16. Beltran, J.C.; Pannell, D.J.; Doole, G.J.; White, B. A bioeconomic model for analysis of integrated weed management strategies for annual barnyardgrass (Echinochloa crus-galli complex) in Philippine rice farming systems. Agric. Syst. 2012, 112, 1-10. [CrossRef]

17. Lacoste, M.; Powles, S. Beyond modelling: Considering user-centred and post-development aspects to ensure the success of a decision support system. Comput. Electron. Agric. 2016, 121, 260-268. [CrossRef]

18. Mahmood, K.; Mathiassen, S.K.; Kristensen, M.; Kudsk, P. Multiple Herbicide Resistance in Lolium multiflorum and Identification of Conserved Regulatory Elements of Herbicide Resistance Genes. Front. Plant Sci. 2016, 7. [CrossRef]

19. Mathiassen, S.K.; Kudsk, P. Etablering af en Status for Forekomst af Herbicidresistens i Danmark (2013-2015); Aarhus University: Aarhus, Denmark, 2016; p. 55.

20. Jensen, P.K. Longevity of seeds of Poa pratensis and Lolium perenne as affected by simulated soil tillage practices and its implications for contamination of herbage seed crops. Grass Forage Sci. 2010, 65, 85-91. [CrossRef]

21. Landbrugsinfo. DK-RIM—et Værktøj Til at Planlægge Langsigtet Bekæmpelse af Italiensk Rajgræs. Available online: https://www.landbrugsinfo.dk/Planteavl/Sider/pl_19_AU_DK_RIM_bekaempelse_italiensk_rajgraes. aspx (accessed on 1 May 2020).

22. Pluske, J.M.; Pannell, D.J.; Bennett, A.L. RIM Reference Manual. A Decision Tool for Integrated Management of Herbicide-Resistant Annual Ryegrass; School of Agricultural \& Resource Economics, The University of Western Australia: Crawley, Australia, 2004.

23. Renton, M.; Diggle, A.; Manalil, S.; Powles, S. Does cutting herbicide rates threaten the sustainability of weed management in cropping systems? J. Theor. Biol. 2011, 283, 14-27. [CrossRef]

24. Jensen, J.E. (Landbrug og Fødevarer F.m.b.a SEGES, Aarhus, Denmark). Personal communication, 2020.

25. Lemerle, D.; Verbeek, B.; Cousens, R.D.; Coombes, N.E. The potential for selecting wheat varieties strongly competitive against weeds. Weed Res. 1996, 36, 505-513. [CrossRef]

26. Stone, M.J.; Cralle, H.T.; Chandler, J.M.; Miller, T.D.; Bovey, R.W. Wheat yield loss in response to Italian ryegrass in diverse environments. J. Prod. Agric. 1999, 12, 229-231. [CrossRef]

27. Lacoste, M.; Pannell, D.; Stewart, V.; Bennett, A.; Monjardinao, M.; Schmidt, C.; Draper, A.; Powles, S. RIM Ryegrass Integrated Model. Available online: https://ahri.uwa.edu.au/research/rim/rim-download/ (accessed on 15 June 2020).

28. Cousens, R. An empirical-model relating crop yield to weed and crop density and a statistical comparison with other models. J. Agric. Sci. 1985, 105, 513-521. [CrossRef]

29. Lutman, P.J.W.; Moss, S.R.; Cook, S.; Welham, S.J. A review of the effects of crop agronomy on the management of Alopecurus myosuroides. Weed Res. 2013, 53, 299-310. [CrossRef]

30. Sieling, K.; Christen, O. Crop rotation effects on yield of oilseed rape, wheat and barley and residual effects on the subsequent wheat. Arch. Agron. Soil Sci. 2015, 61, 1531-1549. [CrossRef] 
31. Bohan, D.A.; Powers, S.J.; Champion, G.; Haughton, A.J.; Hawes, C.; Squire, G.; Cussans, J.; Mertens, S.K. Modelling rotations: Can crop sequences explain arable weed seedbank abundance? Weed Res. 2011, 51, 422-432. [CrossRef]

32. Colbach, N.; Granger, S.; Meziere, D. Using a sensitivity analysis of a weed dynamics model to develop sustainable cropping systems. II. Long-term effect of past crops and management techniques on weed infestation. J. Agric. Sci. 2013, 151, 247-267. [CrossRef]

33. Dorn, B.; Jossi, W.; van der Heijden, M.G.A. Weed suppression by cover crops: Comparative on-farm experiments under integrated and organic conservation tillage. Weed Res. 2015, 55, 586-597. [CrossRef]

34. Moonen, A.C.; Barberi, P. Size and composition of the weed seedbank after 7 years of different cover-crop-maize management systems. Weed Res. 2004, 44, 163-177. [CrossRef]

35. Buchanan, A.; Kolb, L.N.; Hooks, C.R.R. Can winter cover crops influence weed density and diversity in a reduced tillage vegetable system? Crop Prot. 2016, 90, 9-16. [CrossRef]

36. Gerhards, R.; Schappert, A. Advancing cover cropping in temperate integrated weed management. Pest Manag. Sci. 2020, 76, 42-46. [CrossRef]

37. Scherner, A.; Melander, B.; Kudsk, P. Vertical distribution and composition of weed seeds within the plough layer after eleven years of contrasting crop rotation and tillage schemes. Soil Tillage Res. 2016, 161, 135-142. [CrossRef]

38. Jensen, P.K. Longevity of seeds of Poa trivialis and Vulpia myuros as affected by simulated soil tillage practices and straw disposal technique. Grass Forage Sci. 2010, 65, 76-84. [CrossRef]

39. Ichihara, M.; Yamashita, M.; Sawada, H.; Kida, Y.; Asai, M. Influence of after-ripening environments on the germination characteristics and seed fate of Italian ryegrass (Lolium multiflorum). Weed Biol. Manag. 2009, 9, 217-224. [CrossRef]

40. Rasmussen, I.A. The effect of sowing date, stale seedbed, row width and mechanical weed control on weeds and yields of organic winter wheat. Weed Res. 2004, 44, 12-20. [CrossRef]

41. Melander, B. Impact of drilling date on Apera-spica-venti L. and Alopecurus-Myosuroides Huds in winter cereals. Weed Res. 1995, 35, 157-166. [CrossRef]

42. Kristensen, L.; Olsen, J.; Weiner, J. Crop density, sowing pattern, and nitrogen fertilization effects on weed suppression and yield in spring wheat. Weed Sci. 2008, 56, 97-102. [CrossRef]

43. Kirkegaard, J.; Christen, O.; Krupinsky, J.; Layzell, D. Break crop benefits in temperate wheat production. Field Crop. Res. 2008, 107, 185-195. [CrossRef]

44. Llewellyn, R.S.; Lindner, R.K.; Pannell, D.J.; Powles, S.B. Grain grower perceptions and use of integrated weed management. Aust. J. Exp. Agric. 2004, 44, 993. [CrossRef]

45. Hicks, H.L.; Comont, D.; Coutts, S.R.; Crook, L.; Hull, R.; Norris, K.; Neve, P.; Childs, D.Z.; Freckleton, R.P. The factors driving evolved herbicide resistance at a national scale. Nat. Ecol. Evol. 2018, 2, 529-536. [CrossRef]

46. Liebman, M.; Dyck, E. Crop rotation and intercropping strategies for weed mangement. Ecol. Appl. 1993, 3, 92-122. [CrossRef]

47. Skaalsveen, K.; Ingram, J.; Clarke, L.E. The effect of no-till farming on the soil functions of water purification and retention in north-western Europe: A literature review. Soil Tillage Res. 2019, 189, 98-109. [CrossRef]

48. Peigne, J.; Ball, B.C.; Roger-Estrade, J.; David, C. Is conservation tillage suitable for organic farming? A review. Soil Use Manag. 2007, 23, 129-144. [CrossRef]

49. Melander, B.; Munier-Jolain, N.; Charles, R.; Wirth, J.; Schwarz, J.; van der Weide, R.; Bonin, L.; Jensen, P.K.; Kudsk, P. European Perspectives on the Adoption of Nonchemical Weed Management in Reduced-Tillage Systems for Arable Crops. Weed Technol. 2013, 27, 231-240. [CrossRef]

50. Nichols, V.; Verhulst, N.; Cox, R.; Govaerts, B. Weed dynamics and conservation agriculture principles: A review. Field Crop. Res. 2015, 183, 56-68. [CrossRef]

51. Melander, B.; Holst, N.; Jensen, P.K.; Hansen, E.M.; Olesen, J.E. Apera spica-venti population dynamics and impact on crop yield as affected by tillage, crop rotation, location and herbicide programmes. Weed Res. 2008, 48, 48-57. [CrossRef]

52. Gonzalez-Andujar, J.L.; Fernandez-Quintanilla, C. Modelling the population dynamics of annual ryegrass (Lolium rigidum) under various weed management systems. Crop Prot. 2004, 23, 723-729. [CrossRef] 
53. O'Donovan, J.T.; Harker, K.N.; Turkington, T.K.; Clayton, G.W. Combining Cultural Practices with Herbicides Reduces Wild Oat (Avena fatua) Seed in the Soil Seed Bank and Improves Barley Yield. Weed Sci. 2013, 61, 328-333. [CrossRef]

54. Lacoste, M.; Llewellyn, R.; Powles, S.; Pannell, D. RIM 2004 and Workshops: Evaluation-Farmers and Consultants Surveys; Australian Herbicide Resistance Initiative, School of Plant Biology \& School of Agricultural and Resource Economics, The University of Western Australia: Perth, Australia, 2013; p. 9.

55. Colas, F.; Cordeau, S.; Granger, S.; Jeuffroy, M.H.; Pointurier, O.; Queyrel, W.; Rodriguez, A.; Villerd, J.; Colbach, N. Co-development of a decision support system for integrated weed management: Contribution from future users. Eur. J. Agron. 2020, 114. [CrossRef]

56. Wilson, R.S.; Hooker, N.; Tucker, M.; Lejeune, J.; Doohan, D. Targeting the farmer decision making process: A pathway to increased adoption of integrated weed management. Crop Prot. 2009, 28, 756-764. [CrossRef]

57. Moss, S. Integrated weed management (IWM): Why are farmers reluctant to adopt non-chemical alternatives to herbicides? Pest Manag. Sci. 2019, 75, 1205-1211. [CrossRef]

58. Stetkiewicz, S.; Bruce, A.; Burnett, F.J.; Ennos, R.A.; Topp, C.F.E. Perception vs practice: Farmer attitudes towards and uptake of IPM in Scottish spring barley. Crop. Prot. 2018, 112, 96-102. [CrossRef]

(C) 2020 by the authors. Licensee MDPI, Basel, Switzerland. This article is an open access article distributed under the terms and conditions of the Creative Commons Attribution (CC BY) license (http://creativecommons.org/licenses/by/4.0/). 